\title{
Preservatory effect of stored 'Setoka' (Citrus sp.) using the noncontacted low temperature atmospheric pressure surface discharged plasma
}

\author{
Hyun Joo An*, Kyung Jin Park, Sang Suk Kim \\ Citrus Research Institute, National Institute of Horticultural and Herbal Science, RDA, Jeju 63607, Korea
}

\section{비접촉식 저온 대기압 면방전 플라즈마를 이용한 저장 '세토카' 감귤의 선도유지 효과}

\author{
안현주* · 박경진 · 김상숙 \\ 감귤연구소 국립원예특작과학원 농촌진흥청
}

\begin{abstract}
Activity of the noncontacted low temperature atmospheric pressure surface discharged plasma (LASDP) converts stable gas to ionized gas known as discharge or plasma. This ionized gas exhibits the antimicrobial activity. We examined the effects of 3 different storage treatments for 80 days on 'Setoka' : ambient storage (AS), low-tempperature storage (LTS), and low-temperature atmospheric pressure plasma+low-tempperature storage (PLTS). Total soluble solids showed no the significant differences between the 3 treatments. Acidity gradually decreased, and was $0.5 \%$ under AS after 30 days of storage. Fruit firmness increased by a few percent until 40 days of storage. Weight loss in AS was higher than for other treatments. After 80 days of storage, the decay ratio was significantly low in PLTS treatment: (AS, 50.5\%; LTS, 5.6\%; PLTS, 1.9\%). In AS treatment, 73\% of the rotten fruits were infected particularly with green and blue mold; however, only $1 \%$ of the rotten fruits were infected in case of PLTS treatment. In conclusion, LASDP treatment can prevent postharvest decay caused by fungi and is an efficacious alternative extending the shelf-life of citrus fruits.
\end{abstract}

Key words : citrus, plasma, postharvest decay, Setoka

\section{서 론}

‘세토카'는 일본 과수연구소에서 청견(Kiyomi)과 앙코 르(Encore No. 2)의 교잡 과실 쿠치노츠 No. 37(kuchinotsu No. 37)에 머코트(Murcott)를 교배하여 육성한 감귤 품종으 로 짙은 오렌지 색을 띄고 과형은 온주밀감을 닮았으며 과즙은 많고 독특한 맛과 향을 지니고 있다. 껍질이 얇고 벗기기 쉬워 일본뿐만 아니라 우리나라에서도 그 재배면적 이 증가하고 있는 만감류 품종이다(1). '세토카'는 만감류

*Corresponding author. E-mail : hjan67@korea.kr

Phone : 82-64-730-4107, Fax : 82-64-730-4111

Received 7 September 2016; Revised 6 October 2016; Accepted 10 October 2016.

Copyright (c) The Korean Society of Food Preservation. All rights reserved.
중에서도 비교적 짧은 저장력을 가지고 있어 주 수확기인 3 월에 홍수 출하되는 문제점이 있고, 저장과 유통기간 연장 에 있어서도 어려움이 있다(2).

감귤의 저장유통 중 품질열화 및 상품성 저하를 유발하 는 주요 품질인자는 수분증발에 따른 중량감소, 변색, 시듦, 조직감 손실, 당도 저하 등이 있으나, 실제 유통현장에서는 무엇보다도 미생물이나 병충해로 인한 부패과 발생이 가장 직접적인 요인으로 알려져 있다(3). 부패과의 발생 원인으 로는 미숙과, 수확시 상처과, 미생물에 오염된 감귤이나 전처리 과정 중 발생되는 외부 충격에 의한 영향 등이 주요 요인이라고 할 수 있다. 감귤 저장 중 부패과의 발생을 억제 하기 위하여 이미녹타딘 트리아세테이트(iminoctadine triacetate)와 같은 항균성 물질을 사용하고 있으나 잔류농약 에 대한 소비자의 불안 심리를 해소하기 위하여 안전한 천연물질로 대체할 필요성이 커지고 있다(4). 감귤의 선도 
유지를 위한 방법으로는 저온저장(5), controlled atmosphere (CA) 저장(6), modified atmosphere packaging(MAP) 저장(7) 등 저장방법에 대한 연구, 강산성 전해산화수 세척(8), 키토 산 및 칼슘 처리 효과(9), 자몽종자추출물을 이용한 천연항 균제(10)에 관한 연구들이 보고되어 있다.

플라즈마는 제 4 의 물질상태를 지칭하는 말로써 기체가 보다 높은 에너지를 가지게 되었을 때 이온과 전자로 분리 되면서 이들이 갖는 에너지가 서로 평행을 이루는 상태를 말한다. 전리된 가스상태인 플라즈마에는 전자, 양이온, 음 이온, 자유 라디칼, 그리고 자외선 광자 등을 포함한 reactive species가 존재하고 있다(11). Reactive species는 미생물 세 포막을 통해 확산되면서 세포막의 지질과 단백질, 그리고 세포 내의 DNA와 같은 거대분자들과 반응하여 미생물 세 포를 손상시킨다 $(12,13)$. 대기압 면방전 플라즈마 기술은 전기적 방전을 통하여 주변의 기체를 오존 $\left(\mathrm{O}_{3}\right)$, 일산화질소 $(\mathrm{NO})$, 이산화질소 $\left(\mathrm{NO}_{2}\right)$ 등 질소산화물 $\left(\mathrm{NO}_{\mathrm{x}}\right)$ 등으로 전리 시키고, $\mathrm{CO}_{2}$ 나 $\mathrm{C}_{2} \mathrm{H}_{4}$ 등의 기체를 분해시킨다. 저온 대기압 플라즈마가 다양한 종류의 미생물들을 죽일 수 있다는 연구 결과들이 많이 보고되고 있는데 그중에서 특히 박테리아 살균에 탁월한 효과가 있음을 보이고 있으며, 이스트나 곰 팡이 병원균에도 살균효과가 있음이 보고되었다(14).

따라서 본 연구는 '세토카' 저장 시 플라즈마 기술의 수확 후 선도유지효과를 구명하고자 곰팡이, 박테리아 등 병원 성 미생물에 대해 살균작용을 한다고 알려진 대기압 저온 플라즈마를 적용하여 저장기간 동안 플라즈마 처리가 과실 품질에 미치는 영향과 부패억제 효과를 검토하였다.

\section{재료 및 방법}

\section{감귤시료}

'세토카'는 서귀포시 남원읍 과원에서 생산된 과실을 완 전 착색이 이루어진 3월 초에 수확하여 시험재료로 사용하 였다. 상처과, 소과 등 비상품과를 선별한 후 저장고에 들어 가기 전 상온에서 예조처리를 실시하여 중량의 $3 \%$ 를 감소 시켜 저장 처리하였다.

\section{저장 조건}

시험 처리에 사용한 저장 방법은 상온저장, 저온저장 및 저온 조건에 대기압 저온 플라즈마를 처리한 저장 3 가지 형태의 저장방법을 비교하였다. 상온저장은 일반 농가의 창고형 저장고를 이용하였으며, 저온저장은 내부공간이 $3 \times 3 \times 3 \mathrm{~m}^{3}$ 인 감귤연구소 저온저장고를 사용하였고 저온저 장고의 내부온도는 $10 \pm 1^{\circ} \mathrm{C}$, 상대습도는 $80 \pm 3 \%$ 가 되도록 설정하여 수행하였다. 그리고 플라즈마 처리 저장법은 감 귤연구소 저온저장고 내에 대기압 저온 플라즈마 발생기를 설치하여 아래의 조건으로 플라즈마 기체를 발생시키고
생성된 활성종의 농도를 측정하였다. 과실은 $20 \mathrm{~kg}$ 저장 용량의 플라스틱 상자에 담아 각 저장방법별 저장고 내에 5 단으로 쌓은 후 80 일까지 저장하였다. 분석용 시료는 10 일 간격으로 저장고 위치와 높이별로 구분하여 무작위로 샘플 링하여 품질을 조사하였다.

\section{플라즈마 발생 장치 및 활성종 측정}

플라즈마 기체 발생은 $\mathrm{sDBD}$ (surface dielectric barrier discharge) 방식으로 $5 \times 9 \mathrm{~cm}$ 크기의 stripe 형태의 전극판 $(220 \mathrm{~V}, 120 \mathrm{~W})$ 을 이용하였다. 작동 시간은 매일 2시간 간격으로 5 분 동안 동작시켰다. 저장고 내 플라즈마 발생 장치의 작동으로 인해 생성되는 활성종으로 오존(UV-100, eco-sensors, Santafe, NM, USA), 일산화질소 및 이산화질소 (Mezus-210, Kemik Co., Seongnam, Korea)의 량은 각각의 측정센서를 이용하여 실시간으로 측정하였다.

\section{분석방법}

과실의 품질에 영향을 주는 가용성고형물, 산 함량, 경도 등을 3 회 측정하여 평균값으로 조사하였다. 과즙의 가용성 고형물(total soluble solids, TTS) 함량은 과즙 $1 \mathrm{~mL}$ 를 채취 하여 디지털 굴절당도계(PAL-1, Atago, Japan)를 이용하여 측정하고, 산 함량은 과즙 $5 \mathrm{~mL}$ 지시약 페놀프탈레인을 2 3방울 첨가한 후 $0.1 \mathrm{~N} \mathrm{NaOH}$ 로 적정하여 정량한 다음 구연산 값으로 환산하였다. 감귤 과피의 경도 측정은 각 과실의 옆면 세 곳을 직경 $3 \mathrm{~mm}$ probe가 부착된 texture analyzer(Model TA-XT2, Godalming, UK)를 사용하여 측정 하고 그 평균값을 나타내었다. 과실의 중량 감소는 저장 처리 직후의 과실 무게를 측정하고, 저장 기간 동안 초기값 에서 측정시 중량을 뺀 백분율 $(\mathrm{w} / \mathrm{w} \%)$ 로 나타내었다. 부패 율은 샘플링할 과실(300개/3콘테이너)을 선정하여 저장기 간 동안 10 일 간격으로 부패 과실을 선별한 후 전체 과실 수 대비 부패된 과실의 비율을 조사하였다.

\section{결과 및 고찰}

저온 대기압 면방전 플라즈마 장치로부터 발생되는 활성종 플라즈마 장치를 설치한 저온저장고의 공기조성을 측정 해 본 결과 산소 $\left(\mathrm{O}_{2}\right)$ 는 $20.2 \%$, 이산화탄소 $\left(\mathrm{CO}_{2}\right)$ 는 $536 \mathrm{ppm}$ 으로 측정되었다(data not shown). 이는 대기의 공기 조성과 유사한 농도로 저온저장고 시스템 특성상 지속적인 외기의 유입으로 인하여 산소와 이산화탄소의 농도가 대기 조성과 유사하게 유지되고 있는 것으로 보인다. 플라즈마가 작동 하는 동안 오존 $\left(\mathrm{O}_{3}\right)$ 의 농도는 약 $0.94 \mathrm{ppm}$ 으로 일정하게 유지되었으며 질소화합물(NOx)도 플라즈마 처리로 인하 여 발생되는 대표적인 이온화된 기체로 저장기간 동안 약 $40.5 \mathrm{ppb}$ 농도로 일정하게 검지되었다(Fig. 1). 오존은 반감 
기가 짧아 금방 분해되어 잔존하지 않지만, 농도에 따라 인체에 영향을 미칠 수 있다. 오존 농도에 따른 인체 영향에 대해 측정한 자료를 보면 $50 \mathrm{ppm}$ 이상에서 1시간 노출될 경우 생명이 위험하며 20 15 ppm에서는 2시간 이내에 작은 동물들은 사망하고, $10 \sim 5 \mathrm{ppm}$ 에서는 맥박이 증가하고 몸이 아프며 마비증세가 올 수 있으며, $0.5 \mathrm{ppm}$ 에서는 확실히 상부기도에 자극을 느끼며 $0.5 \sim 0.2 \mathrm{ppm}$ 에서 3 6시간 노출 시 시각이 감퇴한다. $0.1 \mathrm{ppm}$ 에서는 확실히 냄새가 나고 코나 목에 자극을 느낀다고 알려져 있다(14). 따라서 본 실험에서 사용한 농도 $1 \mathrm{ppm}$ 의 경우도 인체에 영향을 미칠 수 있는 농도로써 실험자의 안전을 충분히 고려해야 하며 이를 농가에 실용화 할 경우 오존 $\left(\mathrm{O}_{3}\right)$ 에 대한 안전 가이드 라인을 제시해야 할 것이다.

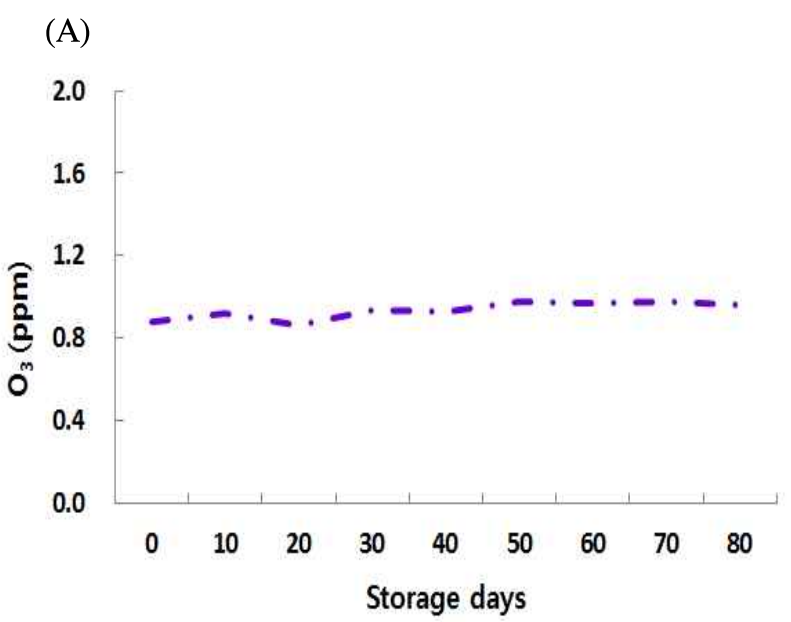

(B)

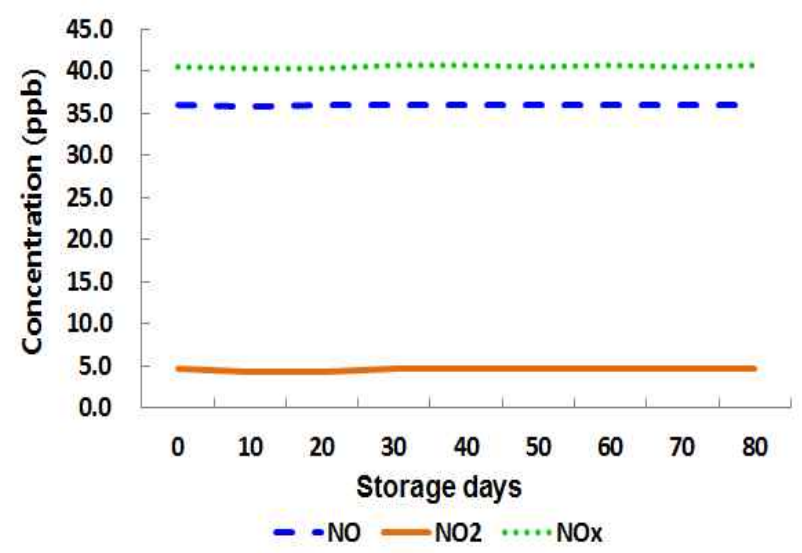

Fig. 1. Measurement of reactive species generated from DBD plasma device.

(A), Concentration of $\mathrm{O}_{3}$ in the storage room during storage; (B), Concentration of $\mathrm{NO}, \mathrm{NO}_{2}$, and $\mathrm{NOX}$ in the storage room during storage.

\section{성분변화}

일반상온저장, 저온저장과 저온저장고에 대기압 저온 플 라즈마를 처리 한 3 가지 저장조건으로 '세토카'를 저장한
후 과일의 식미에 큰 영향을 주는 가용성고형물(Fig. 2)과 산 함량(Fig. 3)의 변화를 조사하였다. 가용성고형물은 저장 초기 당도 $13{ }^{\circ} \mathrm{Brix}$ 의 과실이 저장 80 일 후 상온저장 12.0 ${ }^{\circ} \mathrm{Brix}$, 저온저장 $12.3{ }^{\circ} \mathrm{Brix}$, 저온저장고에 대기압 저온 플라 즈마 처리 경우 $12.6{ }^{\circ} \mathrm{Brix}$ 로 큰 변화를 보이지 않고 거의 일정하게 유지되었다. 산 함량은 저장기간이 경과함에 따 라 저온보다 상온에서 감소 정도가 빨랐으며, 대기압 저온 플라즈마 무처리구가 처리구에 비해 산 함량 감소가 더 많았으나 유의적인 차이는 나타나지 않았다. Lee 등(2)은 ‘세토카' 저장 중 온도에 따른 호흡량을 측정 한 결과 다른 품종에 비해 호흡량이 다소 높고 상온에서는 시간이 경과함 에 따라 저장 온도가 높아져 호흡량이 증가하게 된다고 하였으며, 유기산이 감귤에 있어서 호흡작용의 기질로 사 용되어 산 함량이 감소한다고 보고하였는데(15) 본 실험에 서도 저장 온도가 높은 처리구에서의 산 함량 감소가 빠름 을 확인할 수 있었다.

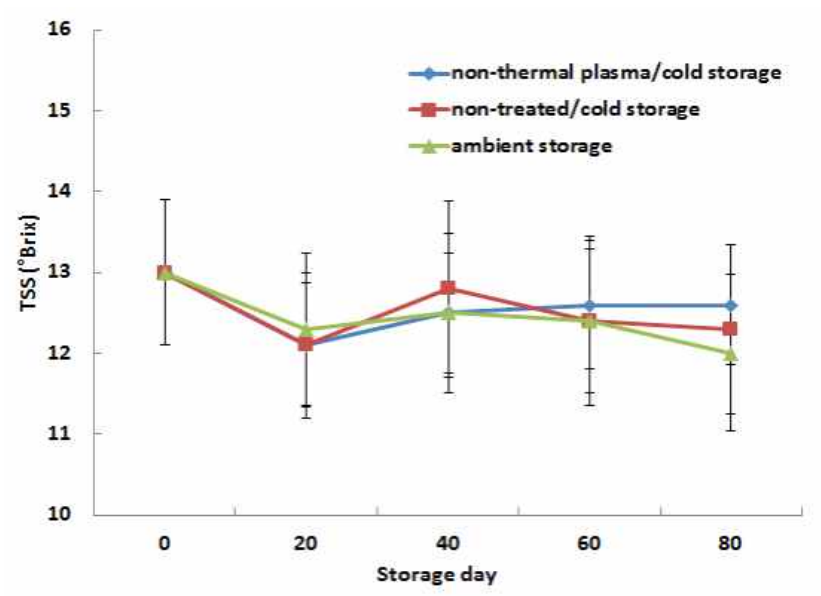

Fig. 2. Total soluble solids of 'Setoka' citrus stored in different storage condition.

Each value is expressed as mean $\pm \mathrm{SD}(\mathrm{n}=3)$.

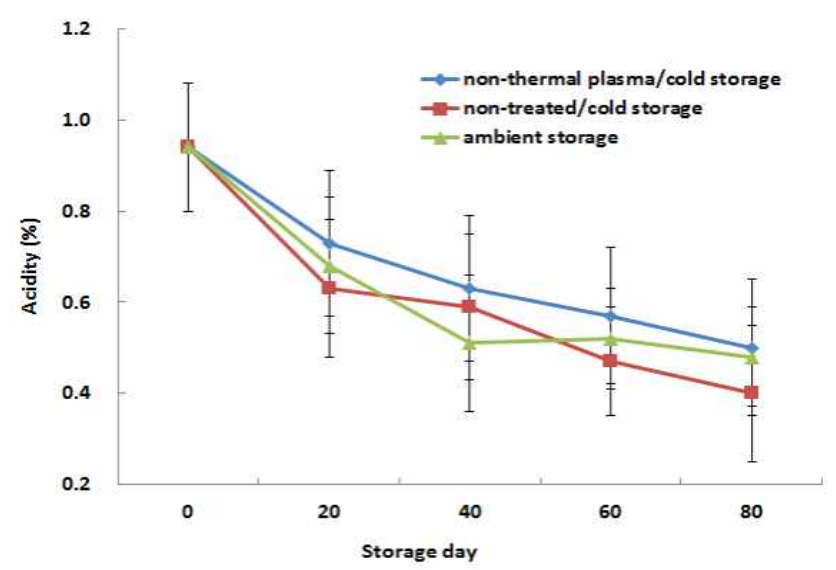

Fig. 3. Acidity of 'Setoka' citrus stored in different storage condition.

Each value is expressed as mean $\pm \mathrm{SD}(\mathrm{n}=3)$. 


\section{물리적 특성 변화}

감귤의 경도(Fig. 4)는 저장 40 일 까지 소폭으로 증가하는 경향이었으나 저장 후반으로 가면서 원래의 경도가 유지되 었으며, 저장방법별 처리에 따른 처리구간의 유의적인 차 이도 구분되지 않았다. Lee 등(3)은 경도 변화의 경우 단순 히 표피의 수분함량보다는 표피와 과육 조직의 복합적인 인자(수분, 칼슴, 펙틴함량 등)에 의해 좌우되기 때문에 일 정한 감소 또는 증가의 경향을 나타내지 않는다고 보고하였 다.

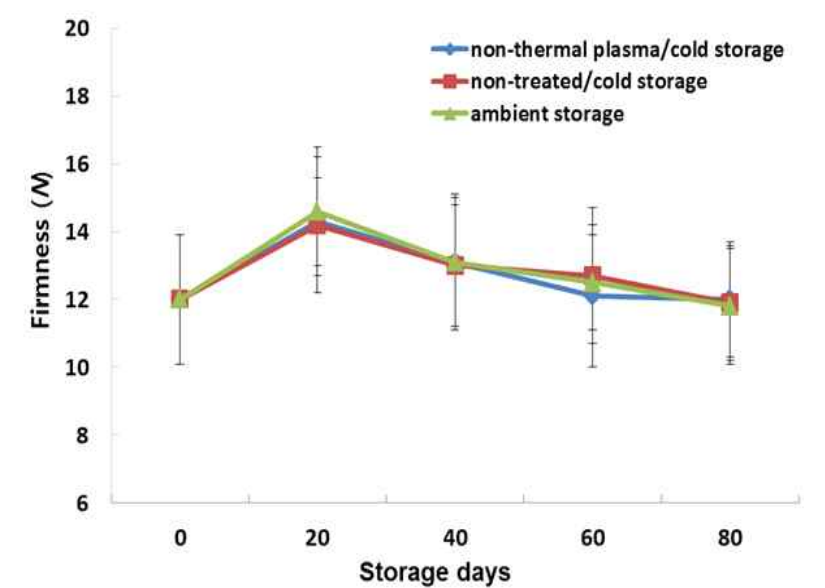

Fig. 4. Firmness of 'Setoka' citrus stored in different storage condition.

Each value is expressed as mean $\pm \mathrm{SD}(\mathrm{n}=3)$.

\section{중량 감소 및 부패율 변화}

‘세토카' 감귤의 저장방법별 저장기간에 따른 감모율의 변화는 Fig. 5와 같다. 저장기간 동안 감모율은 상대적으로 온도 및 습도 유지가 되지 않았던 상온저장에서 현저히 높게 나타났으며, 저온저장 처리구에서는 대기압 저온 플 라즈마 처리구, 무처리구 모두 저장 초기에는 낮은 감모율 을 나타내어 상품성을 유지하였으나, 저장 40 일부터 $5 \%$ 이상의 중량 감소를 보였다. 대기압 저온 플라즈마 처리구 와 무처리구간의 유의적인 차이도 보이지 않았다. 감귤은 수확후에도 계속되는 호흡작용으로 내용성분의 변화 및 과피로부터 수분 증발이 일어난다고 하였다. 그러나 중량 감소는 호흡보다는 과피 표면으로부터의 증산작용에 의해 발생하는 것이 10 배 정도 크다(16)고 하였고, 수확된 과실에 서 발생되는 증산작용은 온도, 습도, 공기유속 등과 같은 환경요인으로부터 영향(17)을 받는데, 본 실험 결과 대기압 저온 플라즈마 처리에 의한 온도 상승이나 증산 촉진과 같은 품질에 영향을 미치는 요인들의 발생이 없었음을 확인 할 수 있었다.

대기압 저온 플라즈마 처리에 의한 부패과 발생 억제효 과를 시험 해 본 결과는 Fig. 6과 같다. 저장 80 일 후 세 처리구에서의 부패과 발생율은 상온저장 $50.5 \%$, 저온저장 $5.6 \%$, 저온저장에 대기압 저온 플라즈마 처리 저장 $1.9 \%$ 이
었다. 상온저장의 경우 저장 20 일째에 부패과가 발생하기 시작하였으며 그 이후 부패가 빠르게 진행되었다. 저온저 장과 저온저장에 대기압 저온 플라즈마를 처리한 경우는 저장 30일 후부터 부패가 시작되었으나 저장 70 일까지 부 패율이 0.5 0.9\%로 낮았고, 특히 대기압 저온 플라즈마를 처리한 처리구에서는 80 일 이후 부패율이 $1.9 \%$ 로 살균효과 가 우수함을 알 수 있었다. 감귤의 유통 및 저장 중 문제시 되는 병으로는 과원의 환경 조건에 따라 다를 수 있지만 Penicillium spp.에 의한 곰팡이 썩음 증세가 가장 피해를 많이 주며 다음으로는 Diaporthe citri에 의한 꼭지썩음병, Alternaria citri에 의한 검은썩음병, Phoma citricarpa에 의 한 검은무늬병 그리고 경우에 따라서는 Botrytis cinerea에 의한 잿빛곰팡이병과 Rhizopus sp.에 의한 무름병도 큰 피해 를 주는 경우가 있다(18). 본 실험 결과 저장방법별로 부패 를 발생시킨 병해의 발생빈도(Table 1)는 상온저장의 경우 약 $73 \%$ 이상이 Penicillium 계통의 곰팡이(푸른곰팡이 $63.3 \%$, 녹색곰팡이 $10.1 \%$ )에 의한 병 발생이 높았으며, 저

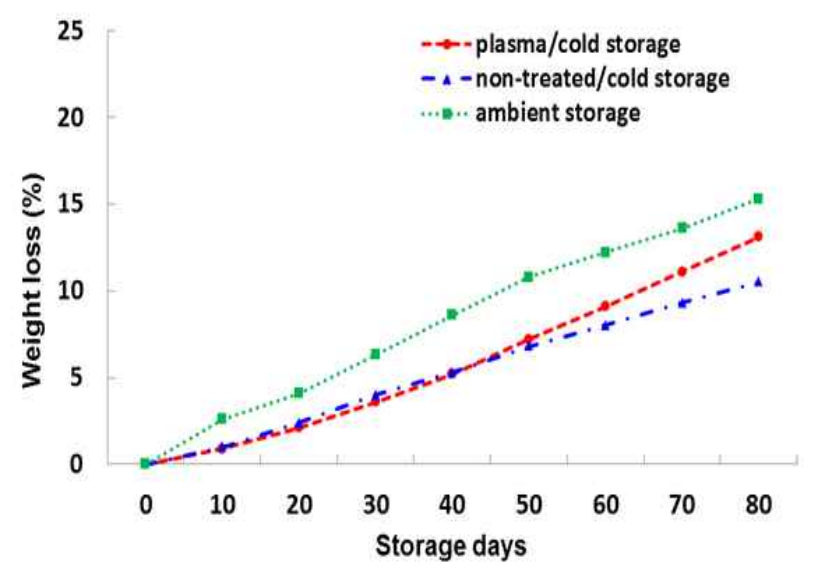

Fig. 5. Weight loss of 'Setoka' citrus stored in different storage condition.

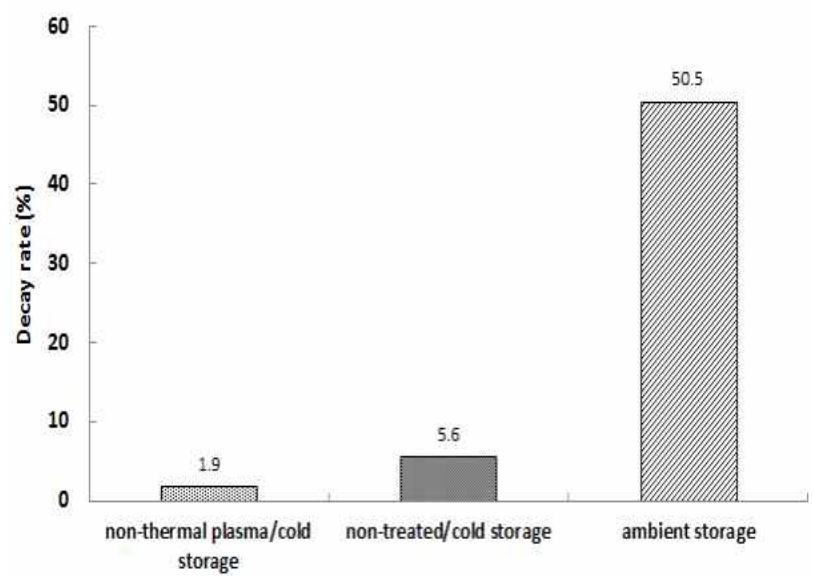

Fig. 6. Decay ratio of 'Setoka' citrus stored in different storage condition. 
Table 1. Frequency of disease occurrence on 'Setoka' citrus after 80 days storage

\begin{tabular}{cccccc}
\hline \multirow{2}{*}{ Storage condition } & \multicolumn{3}{c}{ Occurence (\%) } \\
\cline { 2 - 6 } & Rhizopus fruit rot & Green mold & Black rot & Gray mold & Blue mold \\
\hline Non-thermal plasma/cold storage & 100 & 0 & 0 & 0 & 0 \\
Non-treated/cold storage & 58.3 & 8.3 & 0 & 0 & 33.3 \\
Ambient storage & 22.9 & 10.1 & 0.92 & 2.75 & 63.3 \\
\hline
\end{tabular}

온저장 처리구에서는 곰팡이병 $41.6 \%$, 무름병 $58.3 \%$ 로 발 생하였다. 그러나 저온저장과 대기압 저온 플라즈마를 동 시 처리한 경우, 곰팡이에 의한 저장병 발생은 나타나지 않았으며, 주로 무름병에 의한 과일의 손상만이 나타났다. 일반적으로 곰팡이는 박테리아에 비해서 플라즈마 처리에 의한 살균효과가 적다. 곰팡이는 $\beta$-글루칸( $\beta$-glucan)이라 는 탄수화물로 구성된 세포벽을 가지고 있어 플라즈마에 의한 영향이 박테리아에 비해 다르게 나타날 수 있으며, 또한 많은 곰팡이들이 다양한 색소를 가지고 있으며 이들 색소들은 대체로 많은 경우에 항산화제로 작용할 수 있기에 플라즈마 처리 시 곰팡이가 박테리아에 비해 더 보호받는데 역할을 하는 것으로 보고되었다(14). 부패과의 발생은 주로 감귤시료가 서로 포개져 있는 부위에서 발견되고, 부패과 로부터 다른 과일로의 오염이 전이되어 부패율이 증가하게 되는 대기압 저온 플라즈마처리의 경우 미생물 감염이 시작 된 부위에서만 부패가 진행되고 다른 과일로의 전이 오염이 이루어지지 않음을 알 수 있었다. 이러한 결과는 대기압 저온 플라즈마 처리에 의해 곰팡이 포자의 활성 억제뿐만 아니라 포자가 파괴되어 사멸됨으로써 주위로의 감염이 이루어지지 않는 것으로 생각되어진다. 배추, 양배추, 케일, 양상치 등 생채소류, 감귤, 사과, 포도 및 신선편이 채소류 까지 미생물 및 이물질 제거를 위한 전해수, 염소수 등 다양 한 기능수를 이용한 표면 살균법이 알려져 있지만 염소수, 전해수는 반드시 처리 후 세척 등과 같은 후처리 작업이 필요하며 처리 후 잔존 폐기물의 처리에 어려움이 있는 등 처리 공정이 복잡하다(19-22). 그러나 대기압 저온 플라 즈마 처리는 화학적 유해성과 환경적 오염에 대한 문제점을 해소할 수 있고, 저온 플라즈마 발생기 이용 방법이 용이하 고 처리가 간편하여 쉽게 적용할 수 있다. 또한 발생기 가동 을 위한 부대비용이 적어서 신선 농산물의 선도유지기술로 써의 적용뿐만 아니라 가공식품의 살균 기술로써도 경제적 이고 효율적으로 사용 가능하다.

\section{요 약}

국내 주요 재배되는 만감류 중의 하나인 '세토카'는 시설 재배하여 3월 까지 수확이 이루어진다. 껍질이 얇은 '세토 카'는 저장 중 풍미 변화와 부패율 정도가 다른 만감류에
비하여 상대적으로 높다. 비접촉식 대기압 면방전 저온 플 라즈마 기술은 전기적 방전을 통하여 주변의 기체를 플라즈 마 상태로 전환시키는 것으로 이를 통해 오존 $\left(\mathrm{O}_{3}\right)$ 과 질소산 화물(NOx) 등이 발생되고, 이들 활성종 기체들에 의해 살균 효과를 볼 수 있다. 본 실험에서는 서귀포에서 수확한 '세토 카'를 일반상온저장, 저온저장 $\left(10 \pm 1^{\circ} \mathrm{C}, 80 \pm 3 \%\right)$, 저온저장 에 플라즈마 처리군으로 나누어 80 일 동안 저장하고 10 일 간격으로 품질 및 부패율을 조사하였다. 총 당함량은 3 처리 모두 일정하게 유지되었으며, 산 함량은 저장기간 동안 꾸 준히 감소하였고, 특히 상온저장 처리에서 저장 30 일부터 급격하게 감소하여 $0.5 \%$ 이하의 산 함량을 나타내었다. 경 도는 저장 40 일까지 소폭으로 증가하는 경향이었으나 처리 간 유의적인 차이는 보이지 않았다. 감모율은 상대적으로 저장 온도가 높은 상온저장에서의 중량감소가 컸다. 저장 80 일 후의 부패율은 상온저장 $50.5 \%$, 저온저장 $5.6 \%$, 저온 저장에 플라즈마 처리군에서는 $1.9 \%$ 로 조사되었다. 상온 저장에서 발생된 저장병의 $73 \%$ 가 곰팡이병이었으나 플라 즈마 처리군에서 발생된 부패병은 대부분 무름병 증상이 며, Penicillium 균에 의한 부패병은 발생되지 않움으로써 '세토카' 저장 시 플라즈마의 살균효과를 확인하였다.

\section{감사의 글}

본 연구는 농촌진흥청 지원사업(과제번호: PJ011282012016) 의 지원을 받아 수행되었으며 이에 감사드립니다.

\section{References}

1. Rypji M, Mashahi Y, Takeshi K, Terutaka Y, Nobuhito M, Naomi O, Yoshio Y, Kensuke A, Hidikazu I, Katsuichi Y, Shigeru U, Iwao O, Hirono M (2003) New citrus cultivar 'Setoka'. B Natl I Fruit Tree Sci, 2, 25-31

2. Lee JH, An HY, Lee SY, Choi YH, Lim BS, Kang YJ (2009) Changes in quality characteristics of 'Setoka' (Citrus Spp.) using different storage methods. Korean J Food Preserv, 16, 644-649

3. Lee HH, Hong SI, Son SM, Kim DM (2004) Storage quality of early harvested satsuma mandarin as influenced 
by hot air treatment. Korean J Food Preserv, 11, 304-312

4. Kim SH, Koh JS, Kim BC, Yang YT, Han WT, Kim KH (2001) Effect of chitosan and calcium treatments on the quality of satsuma mandarin during storage. Korean J Postharvest Sci Technol, 8, 279-285

5. Kim SH, Lim JH, Koh JS (2002) Quality changes of satsuma mandarin during storage by storage warehouse. Korean J Food Preserv, 9, 131-136

6. Yang YJ (2001) Postharvest quality of satsuma mandarin fruit affected by controlled atmosphere. Korean J Hort Sci Technol, 19, 145-148

7. Choi YH, Ko SU, Kim SH, Kim YH, Kang SK, Lee $\mathrm{CH}$ (2002) Influence of modified atmosphere packaging on fruit quality of 'Tsunokaori' tangor during cold storage. Korean J Hort Sci Technol, 20, 340-344

8. Song EY, Choi YH, Kim SH, Koh JS (2003) Effect of washing treatment of electrolyzed acid water on shelf-life of greenhouse mandarin fruits during marketing. Korean J Food Preserv, 10, 1-5

9. Kim SH, Koh JS (2003) Quality changes of Citrus kiyomi by chitosan and calcium treatment and storage warehouse. Korean J Food Preserv, 10, 147-153

10. Cho SH, Lee HC, Seo IW, Kim ZU, Chang YS, Shin ZI (1991) Efficacy of grapefruit seed extract in the preservation of satsuma mandarin. Korean J Food Sci Technol, 23, 614-618

11. Bogaerts A, Neyts E, Gijbels R, van der Mullen V (2002) Gas discharge plasmas and their applications. Spectrochimica acta. Part B. Atomic spectroscopy, 57, 609-658

12. Laroussi M, Leipold F (2004) Evaluation of the roles of reactive species, heat, and UV radiation in the inactivation of bacterial cells by air plasmas at atmospheric pressure. Int J Mass Spectrom, 233, 81-86

13. Bol shakov AA, Cruden BA, Mogul R, Rao MVVS, Sharma SP, Khare BN, Meyyappan M (2004) Radio-frequency oxygen plasma as a sterilization source. AIAA J, 42, 823-832
14. Ryu YH, Uhm HS, Park GS, Choi EH (2013) Sterilization of Neurospora Crassa by noncontacted low temperature atmospheric pressure surface discharged plasma with dielectric barrier structure. J of the Korean Vaccum Society, 22, 55-65

15. Murata T (1977) Studies on the postharvest physiology and storage of citrus fruit: VII. Acid metabolism in satsuma mandarin fruit during storage. J Japan Soc Hort Sci, 46, 283-287

16. Lee SK (1997) Postharvest physiology of horticultural crops. Seonggyun Press, Seoul, Korea, p 53

17. Kader AA (2002) Postharvest biology and technology: an overview, in: Kader AA (Editor), Postharvest technology of horticultural crops. Regents of the University of California, Division of Agricultural and Natural Resources, Oakland, CA, USA, p 39-48

18. Hyun JW, Lee SC, Ihm YB, Kim DH, Ko SW, Kim KS (2001) Protective effect of iminoctadine acetate (albesilate) and kresoxim-methyl fungicides to citrus postharvest diseases caused by Penicillium spp. Korean J Pestic Sci, 5, 37-44

19. Jung SW, Park KJ, Park KJ, Park BI, Kim YH (1996) Surface sterilization effect of electrolyzed acid-water on vegetable. Korean J Food Sci Technol, 28, 1045-1051

20. Jin YG, Kim TW, Ding T, Oh DH (2009) Effect of electrolyzed water and citric acid on quality enhancement and microbial inhibition in head lettuce. Korean J Food Sci Technol, 41, 578-586

21. Nimitkeatkai H, Kim JG (2009) Washing efficiency of acidic electrolyzed water on microbial reduction and quality of 'Fuji' apples. Kor J Hort Sci Technol, 27, 250-255

22. Kim SH, Chung HS, Lee JB, Kang JS, Chung SK, Choi JU (2003) Effect of atmosphere sterilization using acidic electrolyzed water on storage quality and microbial growth in grapes. J Korean Soc Food Sci Nutr, 32, 549-554 